\author{
I.A. Ndiaye ${ }^{1}$, A.I. Skripnikova ${ }^{2 *}$ \\ ${ }^{1}$ University Warmia and Mazyry, Poland, Olsztyn \\ ${ }^{2}$ Al-Farabi Kazakh National University, Kazakhstan, Almaty \\ *e-mail: sai.kz@mail.ru
}

\title{
WHAT THE «KAZAKHSTAN TRUTH» NEWSPAPER TELLS ABOUT COVID-19
}

Mass media around the world have actively covered the situation with coronavirus. The current outbreak of infection has been much more famed in media than previous epidemics, like SARS or Ebola. Kazakhstan is no exception. The purpose of this article is to analyze journalistic texts on the coronavirus and tried to highlight existing trends, identify errors and give a description of the overall picture of the stream of publications using the example of country's main newspaper. The scientific significance of the work lies in the fact that earlier similar studies on the topic have not been conducted. In terms of methodology, the content analysis was chosen as the main research method. All published articles were broken into several sectors manually. The data was summarized. Having preliminary sorted all the information, further manually work was carried out to calculate the necessary quantitative data. The value of the work lies in the data obtained during the process of work. The following main results were received: on average, the periodical publishes almost two articles about coronavirus per day; foreign news portals prevail as sources of information; among the genres informational notes and reports from press conferences prevail, and there are no author's interviews or journalistic investigations; vast majority of photographic materials newspaper borrows from Internet, illustrative photographs prevail; most of the journalists in their articles refer to officials and are not looking for independent experts; there is the limit of information and it is simply copied from article to article; the editorial office seeks to maintain neutrality - there is no material that would have a racist, offensive (in relation to the country or infected people) character. All findings were divided into positive and negative. To overcome negative aspects some recommendations were made. This is the main practical significance of the work's results.

Key words: Kazakhstan, mass media, coronavirus, The «Kazakhstan Truth», copyright materials.

\author{
И.А. Ндяй ${ }^{1}$, А.И. Скрипникова ${ }^{2 *}$ \\ ${ }^{1}$ Вармия-Мазур университеті, Польша, Ольштын к \\ ²л-Фараби атындағы Қазақ ұлттық университеті, Қазақстан, Алматы қ. \\ *e-mail: sai.kz@mail.ru \\ «Казахстанская правда» газеті коронавирус туралы не айтты
}

Бүкіл әлемдегі бұқаралық ақпарат құралдары коронавируспен байланысты жағдайды белсенді түрде жариялауда. Қазіргі кездегі инфекцияның өршуі, тақырып ретінде, SARS немесе Эбола сияқты алдыңғы эпидемияларға қарағанда бұқаралық ақпарат құралдарында әлдеқайда танымал. Қазақстан да ерекшелік емес. Бұл мақаланың мақсаты - коронавирус туралы публицистикалық мәтіндерді талдау, қолданыстағы тенденцияларды бөліп көрсету, журналистік қателіктерді анықтау және жарияланымдар ағымының жалпы көрінісін беру (елдің бас газеті мысалында). Жұмыстың ғылыми маңыздылығы - мұндай зерттеулер бұрын жүргізілмейді. Зерттеудің негізгі әдісі ретінде контент-анализ таңдалды. Барлық жарияланған материалдар қолмен бірнеше блоктарға бөлінген. Деректер жинақталған. Бұрын ақпаратты сұрыптағаннан кейін, сандық көрсеткіштерді есептеу бойынша қосымша жұмыстар қолмен жүргізілді. Ғылыми маңызы алынған сандық мәліметтерде жатыр. Зерттеудің негізгі нәтижелері: газет орта есеппен күн сайын коронавирус туралы екі мақала жариялайды; жаңалықтар көзі ретінде шетелдік жаңалықтар порталдары қолданылады; жанрлар арасында ақпараттық жазбалар мен баспасөз конференцияларының баяндамалары қолданылады, автордың сұхбаттары немесе журналистік зерттеулер жоқ; көпшілігінде газет фотосуреттерді Интернеттен алады, иллюстрациялық фотосуреттер басым болады; журналистердің көпшілігі өз мақалаларында шенеуніктерге сілтеме жасайды және тәуелсіз сарапшыларды іздемейді; ақпарат шектеулі және ол жай мақаладан мақалаға көшіріледі; басылым бейтарап болуға тырысады - нәсілшіл, қорлайтын (белгілі бір елге немесе жұқтырған адамдарға қатысты) материалдар жоқ. Барлық көрсеткіштер оң және теріс болып бөлінеді. Жағымсыз жақтарды жеңу үшін бірқатар ұсыныстар беріледі, бұл нәтижелердің практикалық маңыздылығы.

Түйін сөздер: Қазақстан, БАҚ, коронавирус, «Казахстанская правда», авторлық құқықпен қорғалған материалдар. 


\author{
И.А. Ндяй ${ }^{1}$ А.И. Скрипникова ${ }^{2 *}$ \\ ${ }^{1}$ Варминско-Мазурский университет, Польша, г. Ольштын \\ ${ }^{2}$ Казахский национальный университет им. аль-Фараби, Казахстан, г. Алматы \\ *e-mail: sai.kz@mail.ru
}

\title{
Что рассказала «Казахстанская правда» о коронавирусе
}

\begin{abstract}
СМИ всего мира активно освещают ситуацию с коронавирусом. Нынешняя вспышка инфекции, как тема, гораздо популярнее в СМИ, чем все предыдущие эпидемии, такие как SARS или Эбола. Казахстан здесь не исключение. Целью данной статьи является анализ журналистских текстов о коронавирусе, попытка выделить существующие тенденции, выявить ошибки журналистов и дать общую картину потока публикаций на примере основной газеты страны. Научная значимость работы заключается в том, что ранее подобные исследования не проводились. Контент-анализ был выбран в качестве основного метода исследования. Все опубликованные материалы разбиты на несколько блоков вручную. Данные обобщены. Предварительно отсортировав информацию, дальнейшая работа по расчету количественных показателей также проводилась вручную. Ценность заключается в полученных числовых данных. Основные результаты исследования: в среднем периодическое издание публикует две статьи о коронавирусе в день; в качестве источников информации преобладают зарубежные новостные порталы; среди жанров преобладают информационные заметки и репортажи с пресс-конференций, нет авторских интервью или журналистских расследований; фотоматериалы газета заимствует в подавляющем большинстве из Интернета, преобладают иллюстративные фотографии; большинство журналистов в своих статьях ссылаются на чиновников и не ищут независимых экспертов; информация лимитирована, и она просто копируется из статьи в статью; редакция стремится сохранять нейтралитет - нет материалов, которые бы носили расистский, оскорбительный (по отношению к определенной стране или инфицированным людям) характер. Все показатели разделены на положительные и отрицательные. Для преодоления негативных аспектов даны некоторые рекомендации, в этом заключается практическая значимость результатов работы.
\end{abstract}

Ключевые слова: Казахстан, СМИ, коронавирус, «Казахстанская правда», авторские материалы.

\section{Introduction}

The «Kazakhstan Truth» («Kazakhstanskaya Pravda») is state, republican socio-political newspaper, which received its current name in 1932. It was published in Orenburg, Kyzylorda, Almaty. In 1999 the editorial staff moved to Astana. In 2005, the newspaper celebrated its 85th anniversary (Kozybaev et al., 2006). Accordingly, in 2020, the periodical marks 100 years. The rich historical past served as one of the factors in choosing the materials of this particular media for analysis. The second factor was the positive feedback on the work of the mass media from the highest authorities, in particular, the words of the President of the Republic of Kazakhstan K.K. Tokayev; citation: "The «Kazakhstan Truth» has been one of the leading periodical among domestic mass media for many decades. The newspaper reflected the most relevant events in the life of Kazakhstan, discussed the most important issues in the development of society .... In the new historical conditions The «Kazakhstan Truth» has proved its relevance and competitiveness, retaining the recognition of numerous readers» (kazpravda.kz).

For a modern person, it's not the quantity of news that matters, but the quality of the streams, therefore more and more people when they want to know the news use the Internet (infpol.ru). That is why the circulation of the newspaper of more than one hundred thousand copies (distributed throughout all regions of the country), is currently not a clear indicator of popularity. However, it should be noted that The «Kazakhstan Truth» is published in electronic version in two languages at once: Russian and English, which significantly expands the audience due to the international segment.

This is how the periodical positions itself in the media space: «The «Kazakhstan Truth» - national daily newspaper is the most important source of official and business information. On its pages the decrees and orders of the Head of state, resolutions of Parliament and the Head of government, new laws of the Republic, messages on rearrangements in the highest authorities are published ... Publications of The «Kazakhstan Truth» enable readers to learn as much as possible about real life in the republic» (kazpravda.kz).

This is a number of reasons why the subject of research was chosen.

Selected subject is a topical issue, an outbreak of a new type of coronavirus (COVID-19), affecting several countries of the world, currently worries everyone. 
For weeks, news outlets around the world have covered the coronavirus. Television channels have been flooded with information about the outbreak that originated in China with live updates. The media has diligently reported on the number of deaths, infected patients as well as possible causes of the virus (Radu, 2020).

The current outbreak has been much more prominent in media coverage than recent epidemics, including Ebola. For example, the «Time Magazine» study shows that there were 23 times more articles in English-language print news covering the coronavirus outbreak in its first month compared to the same time period for the Ebola epidemic in 2018.

100 high-circulation newspapers from around the world have collectively published 9,387 stories about the outbreak. Of these, 1,066 articles mention «fear» or related words, including «afraid»...Such stories often used other frightening language - for example, 50 articles used the phrase «killer virus» (Wahl-Jorgensen, 2020).

In the journalistic article «How global media covers the coronavirus» (Radu, 2020), the author gives examples and analyzes errors when covering the topics of such major world periodicals as: «Daily mail» (Great Britain), «Le Courrier picard» (France), «Der Spiegel» (Germany). All these media had to apologize after publications with shades of racism and xenophobia.

The theme of coronavirus is also covered in all Kazakhstani media, without no exception. And, it would be interesting to conduct a research of domestic texts. Indeed, earlier such scientific studies for obvious reasons have not been conducted.

Kazakhstan, as in many other countries of the world, was quarantined. For many citizens the main sources of information during quarantine were social networks and official media. And, if in social media each person can create a news feed to his/her taste, from the desired sources, then in the state media this is not possible. Therefore, it is very important to evaluate information published precisely in state media.

So, using the example of the main newspaper of the Republic of Kazakhstan, let's try to analyze journalistic texts on the coronavirus and try to highlight existing trends, identify journalistic errors and give a description of the overall picture of the stream of publications.

\section{Materials and methods}

The total number of publications based on search results on the official website of the newspaper (www.kazpravda.kz) for the keyword «coronavirus» from the moment the electronic version appeared until February 20, 2020 - fifty three materials. They will become the main material of the study.

Five publications were cut off from the main array, since they are not related to the issue under discussion. Publication dates: May 14, 2015; May 18, 2015; October 13, 2015; August 11, 2017; May 15,2018 . These materials cover situations with other types of coronovirus, such as MERS (Middle East Respiratory Syndrome), SARS and PDCoV (swine virus), so they are not of particular interest to us.

Let us clarify that publications in Russian are considered. Upon completion of the study, the results are translated into English.

The content analysis was chosen as the main research method, which allows us to give both a qualitative and a quantitative assessment. All published articles were fully read and were broken into several sectors manually. All data is summarized in the final table, where the information is placed in several sections. Having preliminary sorted all the data, further work was carried out to calculate the necessary quantitative data. All calculations were also made manually. A small volume of articles allowed this. In addition, due to the specifics of Kazakhstani media materials, namely the presence of local words in the texts (for example, akim - the head of the city) and language markers, the use of any computer programs for data analysis would give distorted results.

So, in each published material, the following criteria were highlighted: date of publication; material name; number of views; author (journalist); publication initiator (source links); authorship of photographic materials; speakers, experts; keywords; characteristic of coronavirus. All data are tabulated. See excerpt from Table 1. 
What the «Kazakhstan Truth» newspaper tells about COVID-19

Table 1 - Summary of materials on coronovirus published in the newspaper «Kazakhstan Truth». Fragment

\begin{tabular}{|c|c|c|c|c|c|c|c|}
\hline № & Date & $\begin{array}{l}\text { Material } \\
\text { Name } \\
\text { (number of } \\
\text { views) }\end{array}$ & $\begin{array}{l}\text { Author } \\
\text { (journalist) }\end{array}$ & $\begin{array}{l}\text { Links to the } \\
\text { source of } \\
\text { information. } \\
\text { Initiator }\end{array}$ & $\begin{array}{l}\text { Authorship } \\
\text { of photo } \\
\text { materials }\end{array}$ & $\begin{array}{l}\text { Speakers. Experts } \\
\text { References }\end{array}$ & $\begin{array}{c}\text { Keywords } \\
\text { (how coronavirus is } \\
\text { described) }\end{array}$ \\
\hline 1 & 23.01 .2020 & $\begin{array}{l}\text { Due to the } \\
\text { deadly } \\
\text { coronavi- } \\
\text { rus on the } \\
\text { border of } \\
\text { Kazakhstan } \\
\text { and China } \\
\text { tightened } \\
\text { control } \\
(2330)\end{array}$ & $\begin{array}{c}\text { Ekaterina } \\
\text { Eliseeva }\end{array}$ & $\begin{array}{c}\text { Press } \\
\text { conference } \\
\text { in Nur Sultan }\end{array}$ & today.kz & $\begin{array}{l}\text { Deputy Chairman } \\
\text { of the Committee } \\
\text { for Quality and } \\
\text { Safety Control } \\
\text { of Goods and } \\
\text { Services of the } \\
\text { Ministry of Health } \\
\text { of the Republic } \\
\text { of Kazakhstan } \\
\text { Zhandarbek } \\
\text { Bekshin }\end{array}$ & $\begin{array}{l}\text { lethal type of coronavirus } \\
(2) ; \\
\text { remote thermometric } \\
\text { control; } \\
\text { sanitary quarantine points; } \\
\text { symptoms of coronavirus; } \\
\text { reminders with preventive } \\
\text { measures }\end{array}$ \\
\hline 2 & 26.01 .2020 & $\begin{array}{l}\text { Chinese sci- } \\
\text { entists have } \\
\text { successfully } \\
\text { identified a } \\
\text { new coro- } \\
\text { navirus } \\
\text { for vaccine } \\
\text { manufactur- } \\
\text { ing } \\
(3726)\end{array}$ & & $\begin{array}{l}\text { China Daily } \\
\text { News agency }\end{array}$ & $\begin{array}{l}\text { NIAID } \\
\text { (National } \\
\text { Institute of } \\
\text { Allergy and } \\
\text { Infectious } \\
\text { Diseases, } \\
\text { USA) }\end{array}$ & $\begin{array}{c}\text { Head of the } \\
\text { Institute of Viral } \\
\text { Diseases at the } \\
\text { Center for Disease } \\
\text { Control and } \\
\text { Prevention. Name } \\
\text { not specified }\end{array}$ & $\begin{array}{l}\text { new deadly coronavirus; } \\
\text { the new coronavirus that } \\
\text { caused the epidemic in } \\
\text { China; } \\
\text { the desired strain for } \\
\text { the manufacture of the } \\
\text { vaccine; } \\
\text { the first case of recovery } \\
\text { infected with a new } \\
\text { coronavirus }\end{array}$ \\
\hline 3 & 26.01 .2020 & $\begin{array}{l}\text { Atyrau } \\
\text { residents } \\
\text { scared by } \\
\text { fake about } \\
\text { patient with } \\
\text { coronavirus } \\
(1520)\end{array}$ & & $\begin{array}{l}\text { My city News } \\
\text { Portal } \\
\text { press service } \\
\text { of the Health } \\
\text { Department of } \\
\text { Atyrau region }\end{array}$ & $\begin{array}{l}\text { Global Look } \\
\text { Press }\end{array}$ & & $\begin{array}{l}\text { deadly coronavirus; } \\
\text { distribution of false } \\
\text { information; } \\
\text { the first symptoms; } \\
\text { doctors recommend } \\
\text { immediately seeking help }\end{array}$ \\
\hline 4 & 29.01 .2020 & $\begin{array}{l}\text { Impossible } \\
\text { to close the } \\
\text { border }(300)\end{array}$ & $\begin{array}{l}\text { Natalia } \\
\text { Hakobyan }\end{array}$ & & & $\begin{array}{l}\text { Chief Sanitary } \\
\text { Doctor of the } \\
\text { Republic of } \\
\text { Kazakhstan } \\
\text { Zhandarbek } \\
\text { Bekshin }\end{array}$ & coronavirus infection \\
\hline
\end{tabular}

\section{Results and discussion}

We begin by conducting a qualitative and quantitative analysis of materials published in the media from January 15, 2020, when the newspaper first reported a new type of coronavirus. An article entitled: «In China, they talked about the symptoms of a new type of coronavirus» was created by the media editorial board based on materials from «Ria.ru». Photographic materials were also not their own, they were borrowed from Fotolia / Sudok1. The editors describe the virus as «pneumonia of unknown origin», «a new type of coronavirus». Also on the pages of the newspaper there was first official information that «the virus can provoke damage to the respiratory system». Maria Van Kerkkhove, head of the new diseases unit of WHO (World Health Organization), acts as an expert in the article. Readers viewed the electronic version of the article 2286 times (the number of views was taken by us as an indicator of the popularity of the material). Immediately, we note that if there was an opportunity to leave comments on the newspaper's official website, none of the readers took advantage of this opportunity, there were not questions or other types of feedback. 


\section{Quantitative indicators}

The first item in the analysis was the quantitative indicators of the articles, specifically the number of published articles on the topic per day. As can be seen from the graph, the topic reached its maximum surge in the period from January 30 to February 7. Maximum rates - six articles per day (February 3 and
5). There are also days on which the newspaper did not publish materials about coronavirus at all: press conferences and briefings were not held, official information was not received from the Ministry of Health and other organizations in the form of press releases, and there was no initiative from journalists' side. On average, the periodical publishes almost two articles per day (1.84). Details are given in Figure 1.

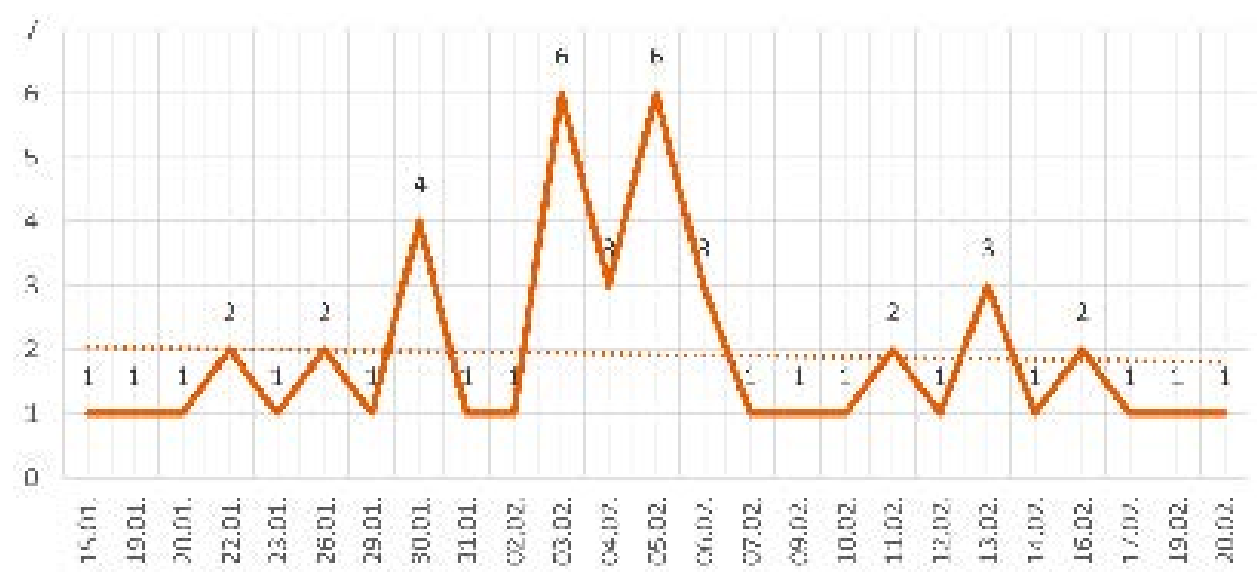

Figure 1 - The number of published materials on coronavirus per day in the newspaper «Kazakhstan Truth»

Further, based on the number of views of each published material, a peculiar rating of the popularity of articles was compiled.

Therefore, according to the received data, the highest rated material was published on February 11, 2020. An article entitled «Riots in the Kordai region and coronavirus: Elbasy held a meeting of the Security Council of the Republic of Kazakhstan» received 4,296 views on the mass media's official website.

Meanwhile, for comparison, the most unpopular material among Internet users is the article «Isolated and Hospitalized» - just 70 views. It was published on February 6, 2020. On the same day, an article was published, which ranks second in the rating - 4,077 views - «The doctor who first warned of coronavirus died in Wuhan». This fact indicates that the publication date does not affect the popularity of the material.

Also, the number of articles per day, according to the graph, does not affect popularity. The second place in the number of views was taken by the material, which was published third on the day of February 6, 2020. Details are presented in Figure 2.

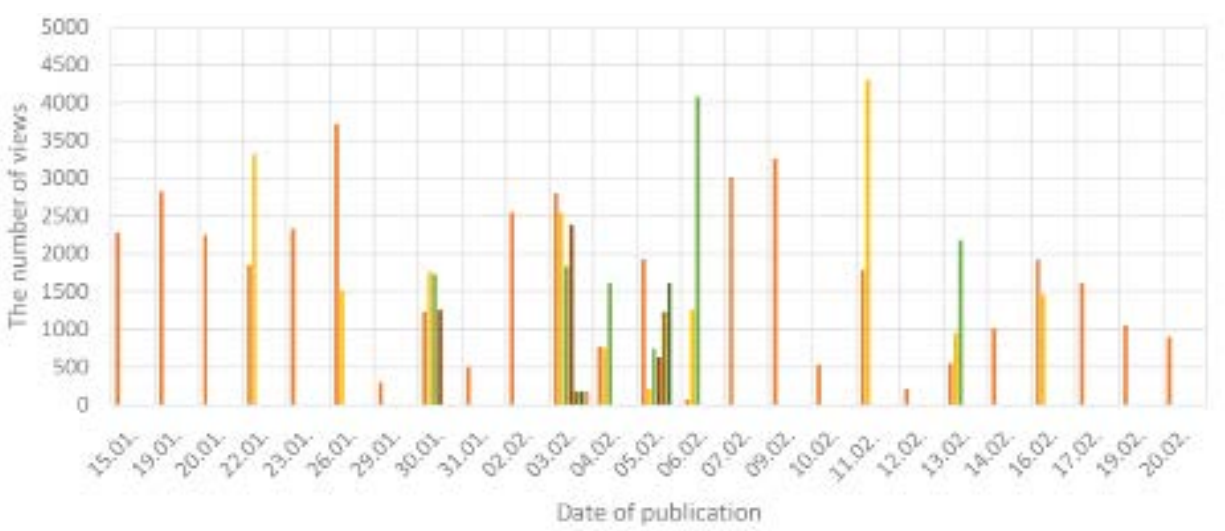

Figure 2 - Number of views (popularity) of articles on coronavirus on the official website of the newspaper «Kazakhstan Truth» 


\section{Qualitative indicators}

Further, during the period under consideration, twenty six copyright materials and twenty two materials were recorded without an indication of the author. Information portals prevail as sources of information, in particular, the newspaper borrowed and adapted to its format and style thirteen materials from «Ria.ru». Among the sources of information are: «BBC.com», «China Daily», «My city», the official website of the Ministry of Health of the Republic of Kazakhstan and even posts on social media. Details about authorship of published materials are presented in Figure 3.

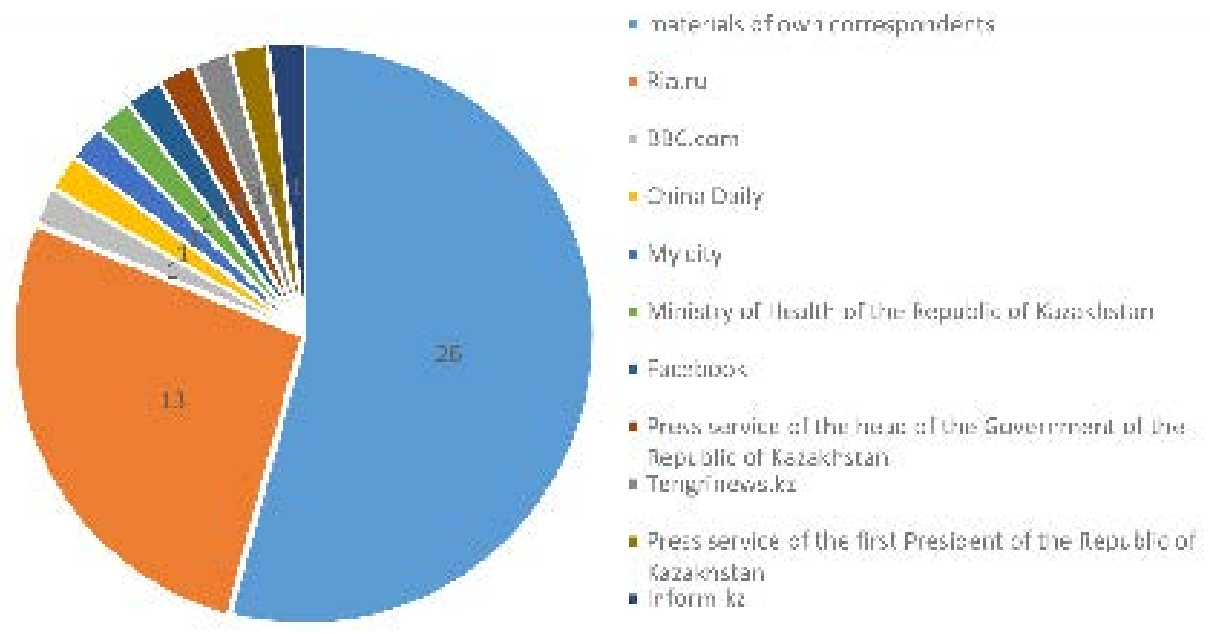

Figure 3 - Authorship of materials on coronavirus in the newspaper «Kazakhstan Truth»

Further, among the materials where the surname and name of the journalist are indicated, a statistics was also carried out for specific authors.

As follows from the collected data, two journalists: Zhanat Tukpiev and Aidan Demesinov wrote seven articles each; Ekaterina Eliseeva - four, the rest are the authors of one material. Note that if a journalist constantly writes on the same subject, he becomes an expert in the field. But, given the fact that among the materials prevailing informational notes, reports from press conferences, and there are no author's interviews, journalistic investigations and other journalistic genres, it's impossible to talk about the presence of an expert journalist in the editorial office. Detailed analysis of copyright materials showed the following results. See Figure 4.

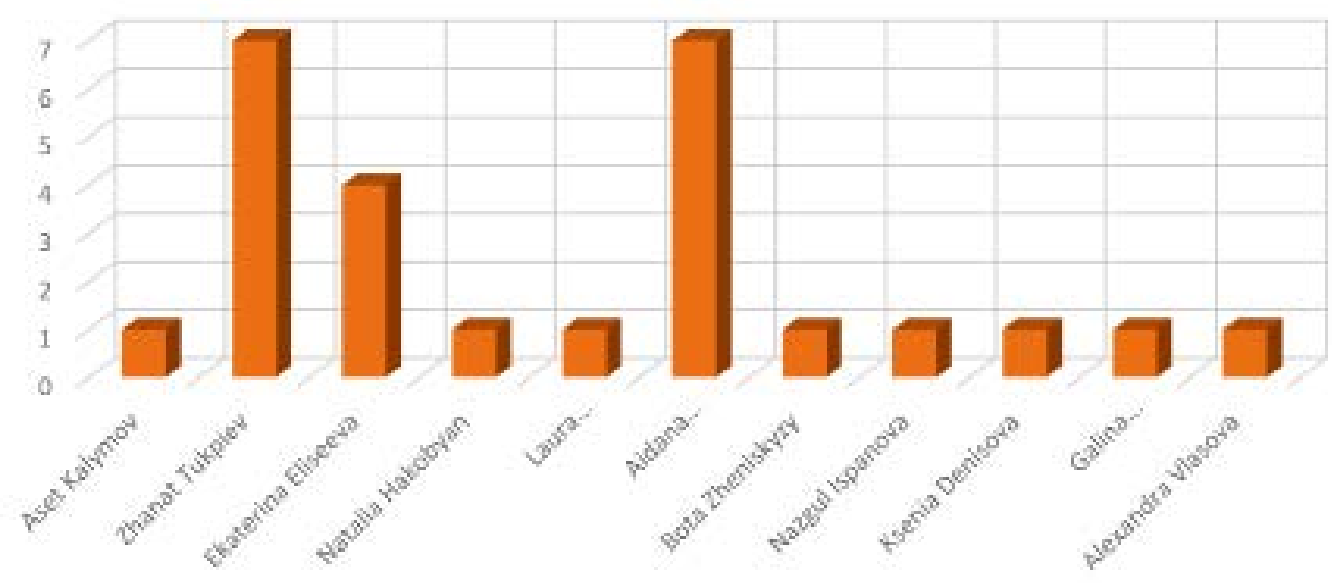

Figure 4 - The number of copyright materials of specific journalists 
Let's look at the data concerning the illustrative accompaniment of articles in the newspaper. According to the collected information, illustrative photographs prevail in The «Kazakhstan Truth», here we should explain that illustrative photographs are not directly related to the event or news, they simply reflect the general idea of medicine or of this or that medical equipment. These can be standard situations in a hospital; they depict medical workers, medical rooms, patients from the back, graphic elements related to medicine, etc. Often compiling materials into issues, the editors do not even notice that in a few days only so-called illustrative photos were published. Sometimes even the same illustration is used in different materials. For example, as it shown in Screenshot 1.
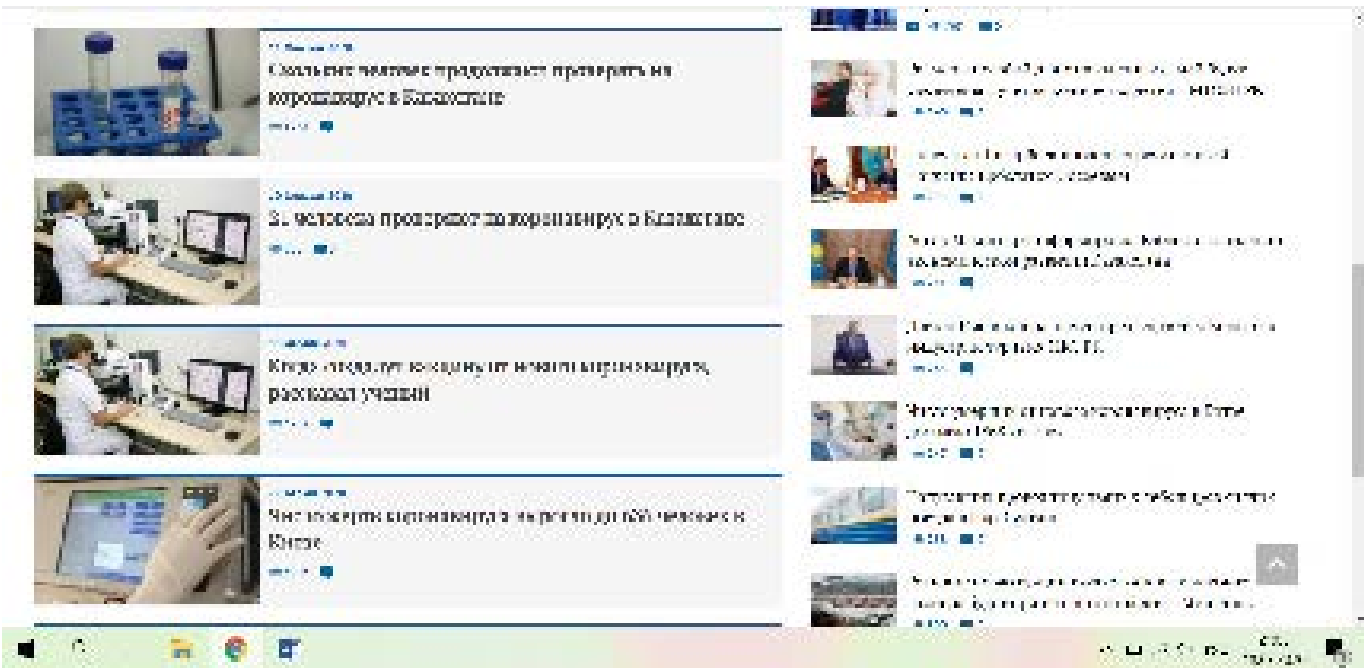

Screenshot 1 - Articles with the illustrative accompaniment on the coronavirus from the website of the newspaper «Kazakhstan Truth»

During the period under review, the media published twelve articles with illustrative photographs. Five articles without a photo. Four articles with photographs where the authorship of the images was not indicated. Only two copyrighted photographs were published in the newspaper, and both of them were taken at a press briefing. The vast majority of photographic materials the newspaper borrows from Internet portals and photo-bases. According to international practice, articles with images get 94\% more total views (Bullas, 2020). This, perhaps, explains the desire of the editorial board to publish articles with photographs, even though borrowing photos negatively affects the media image. Detailed data on photographic materials are presented in Figure 5.

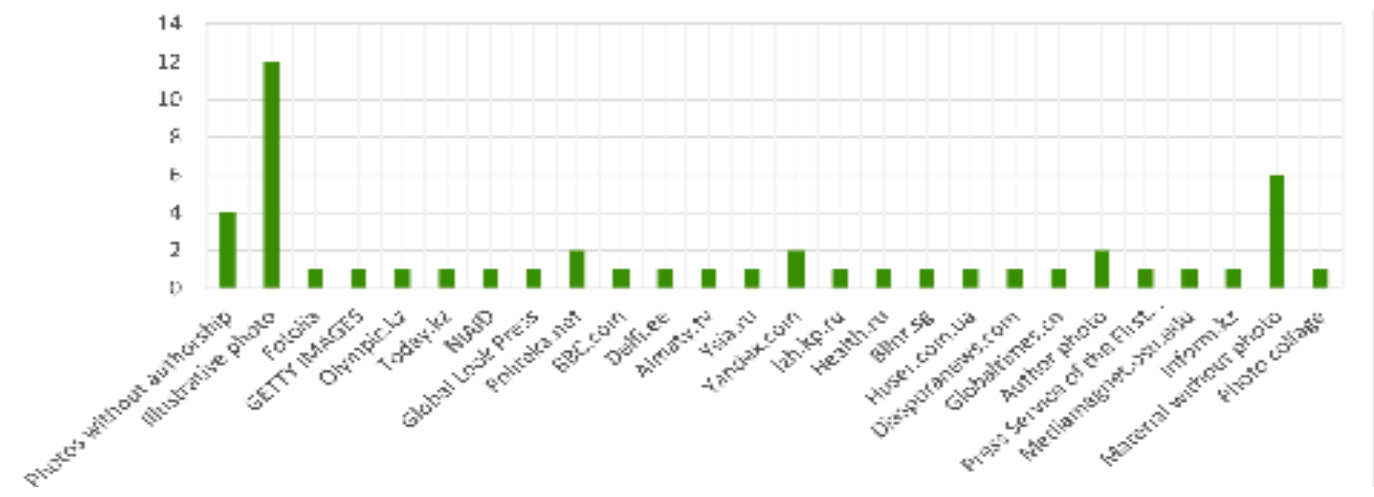

Figure 5 - Number of photographic materials for articles on coronavirus in the newspaper «Kazakhstan Truth» by categories 
The next factor by which we can consider the quality of articles is the involvement of experts, the insertion of citations into the text, direct speech; attracting experts to comment on the situation, «the presence in the materials of specialists whose opinion can be trusted».

As follows from the data, most of the journalists in their articles refer to officials of the Republic of Kazakhstan $-23 \%$. This is explained by the fact that the most part of the author's materials were written on the basis of press conferences at which public servants report to the population.

Yelzhan Birtanov, Minister of Health of the Republic of Kazakhstan, takes the second place in citation (17\%). He was singled out from the «officials» category as a separate one, since he is directly responsible for the situation with the coronavirus. If we combine the obtained numerical data, we get $40 \%$. $40 \%$ of all speakers are representatives of the state apparatus. This fact indicates that journalists are not taking the initiative and are not looking for independent experts.

Third place - experts from the field of medicinethese are doctors and professors. However, it is worth noting that these are specialists who were contacted by other media, and not directly by the workers of The «Kazakhstan Truth». They just reprinted quotes from other media.

Note that in $14 \%$ of all materials there are no speakers at all; and in $6 \%$ the position is indicated but there is no name or surname, which is an indicator of unprofessionalism from the journalist's side and inattention from the issuing editor's side.

It is necessary to focus on the fact that Xi Jinping, President of the PRC, scored a large percentage of citation (14\% of the materials) only because one of his phrase: "The epidemiological situation in the country is serious and complex». It was reprinted word for word by the newspaper without any changes and additions nine times in nine different materials from different authors.

In particular, in the articles: «Why we are not doing rapid tests for coronavirus at the airports of Kazakhstan, explain Birtanov»; "The coronavirus is excluded from the Kazakhstanis who arrived from China - Ministry of Health»; "Stop sending fakes to each other - the Ministry of Health reports about coronavirus»; «Almost 200 fakes about coronavirus were recorded by international organizations - the Ministry of Health of the Republic of Kazakhstan»; "In Wuhan, the doctor who first warned of coronavirus died»; "More than 200 people arrived on a special flight from Beijing to Almaty»; "When Kazakhstani students evacuated from Wuhan will be discharged»; "Kazakhstan is ready to develop a vaccine against coronavirus - the head of the Ministry of Health»; «Two passengers of the Diamond Princess liner have died from a coronavirus».

This fact, which regular readers of the newspaper could not fail to notice, is not in favor of the editors. This is an indicator that there is limited information and it is simply copied, wandering from article to article.

Based on the above headings, we can conclude - no creative undertakings. Yes, this may be connected with the topic itself, it is too serious and does not carry a creative beginning, but even this fact does not justify the presentation of information according to a template, which does not facilitate the perception of facts. The article titles themselves are a prime example of using one template. In addition, the iteration of the same information from day to day, signals the inability of the media to find the data, which is needed to the audience. Details are presented in Figure 6.

As for the analysis of keywords in each article - the editorial office seeks to maintain neutrality - the bulk of the words are neutral. Everything is to be expected - state media in Kazakhstan rarely publish assessment
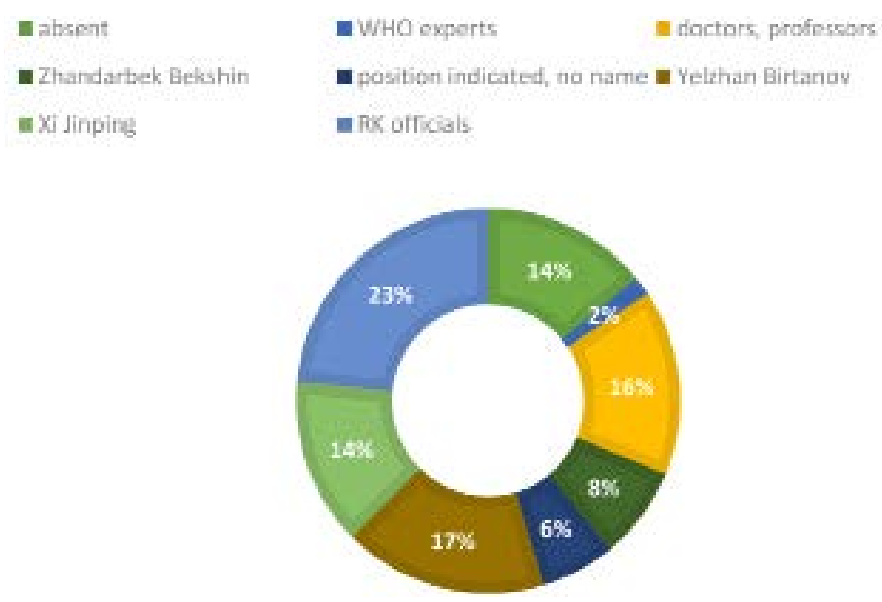

Figure 6 - Cooperation with experts, speakers 
materials; there is no personal opinion of journalists in the materials. There is no material that would have a racist, offensive (in relation to the country or infected people) character, which is a positive feature for the county, apart from other countries. A new global health crisis that have included misleading reports and even racist tones, the international media has struggled to make sense of the new strain of coronavirus, being both lauded and criticized by media experts. Analysts say coverage has been carried in areas not yet exposed to the virus and has included some racial stereotyping, while not enough attention has been focused on real stories shared by patients (Radu, 2020).

\section{Conclusion}

After monitoring and analysis of publications of the main official print mass media of the Republic of Kazakhstan, based on the obtained data, the following main conclusions can be drawn:

1. On average, the periodical publishes almost two articles about coronavirus per day.

2. The publication date and the number of articles per day does not affect the popularity of the concrete material.

3. Information portals prevail as sources of information.

4. It's impossible to talk about the presence of an expert journalist in the editorial office.

5. Among the materials prevailing informational notes, reports from press conferences, and there are no author's interviews, journalistic investigations and other journalistic genres.

6. Illustrative photographs prevail in The «Kazakhstan Truth».

7. The vast majority of photographic materials the newspaper borrows from Internet portals and photo-bases.

8. Most of the journalists in their articles refer to officials of the Republic of Kazakhstan.

9. Journalists are not taking the initiative and are not looking for independent experts.

10. There is the limit information and it is simply copied, wandering from article to article. Iteration of the same information from day to day, signals the inability of the media to find the data, which is needed to the audience.

11. The editorial office seeks to maintain neutrality - the bulk of the keywords about the situation with coronavirus are neutral. There is no material that would have a racist, offensive (in relation to the country or infected people) character.

All findings can be divided into positive and negative. To overcome the negative aspects associated with the lack of official information on the coronavirus, the editorial board could well use the services of translators. There is no shortage or lack of information in English. Even the Coronavirus Information Center (elsevier.com) has been opened. The publication of quickly translated materials could significantly increase the rating of the publication. Alternatively, one might consider creating a rubric in which doctors could write.

As for the complete absence of copyright photographs, as an alternative solution to this problem could be infographics, a format that is now gaining great popularity among the audience due to its simplicity and illustrative presentation of the data.

Research data of the study can be used in the future when conducting similar studies in related fields.

The study is not part of a public or private grant/ program and has not been sponsored by any party.

\section{References}

Bullas, J. (2020). 6 powerful reasons why you should include images in your marketing - infographic. Retrieved from https:// www.jeffbullas.com/6-powerful-reasons-why-you-should-include-images-in-your-marketing-infographic/.

Coronavirus Information Center. Retrieved from https:/www.elsevier.com/connect/coronavirus-information-center.

Infpol. Почему большинство людей предпочитает узнавать новости в интернете [Why do most people prefer to learn news on the Internet]. Retrieved from https://www.infpol.ru/97442-pochemu-bolshinstvo-lyudey-predpochitaet-uznavat-novosti-v-internete/.

Official website of The «Kazakhstan Truth». Казахстанская правда. Особенности издания [Kazakhstan Truth. Edition Features]. Retrieved from https://www.kazpravda.kz/page/view/o-gazete.

Official website of The «Kazakhstan Truth». Глава государства поздравил коллектив республиканской газеты «Казахстанская правда» [The head of state congratulated the staff of the republican newspaper «Kazakhstan Truth»]. Retrieved from https://www.kazpravda.kz/news/prezident2/glava-gosudarstva-pozdravil-kollektiv-respublikanskoi-gazeti-kazahstanskaya-pravda.

Radu, S. (2020, February 7). How global media covers the coronavirus. USNews. Retrieved from https://www.usnews.com/news/ best-countries/articles/2020-02-07/how-the-global-media-covered-stories-about-the-coronavirus-outbreak.

Wahl-Jorgensen, K. (2020, February 15). Coronavirus: how media coverage of epidemics often stokes fear and panic. TheConversation. Retrieved from http://theconversation.com/coronavirus-how-media-coverage-of-epidemics-often-stokes-fear-and-panic- 131844 . 